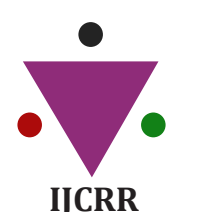

IJCRR

Section: Healthcare

Sci. Journal Impact

Factor: $6.1(2018)$

ICV: 90.90 (2018)

(c) (7) (5)

Copyright@IJCRR

\section{Problems Faced by Daily Labourers During COVID-19 Lockdown - A Questionnaire Survey}

\section{Titus Lalith Antony P. ${ }^{1}$, Leslie Rani ${ }^{2}$, Brundha M. P. ${ }^{3}$, Jothi Priya ${ }^{4}$}

'Saveetha Dental College and Hospitals, Saveetha Institute of Medical and Technical Sciences, Saveetha University, Chennai 77, Tamil Nadu, India; 'Lecturer, Department of General Pathology, Saveetha Dental College and Hospitals, Saveetha Institute of Medical and Technical Sciences, Saveetha University, Chennai 77, Tamil Nadu, India; ${ }^{3}$ Associate Professor, Department of General Pathology, Saveetha Dental College and Hospitals, Saveetha Institute of Medical and Technical Sciences, Saveetha University, Chennai 77, Tamil Nadu, India; ${ }^{4}$ Associate Professor, Department of Physiology, Saveetha Dental College and Hospitals, Saveetha Institute of Medical and Technical Sciences, Saveetha University, Chennai 77, Tamil Nadu, India.

\title{
ABSTRACT
}

Aim: The aim of this study is to get knowledge about the crisis and to create awareness about the problems faced by the daily laborers during the lockdown.

Introduction: The worldwide COVID-19 pandemic is perpetrating two sorts of shock on nations: a health shock and an economical shock. The imposition of social distancing, self-isolation at home, closure of institutions, industries, and public facilities, restrictions on mobility can conceivably prompt critical ramifications for economies around the globe, which affects the survival of the daily laborers.

Materials and Method: The questionnaire is prepared to comprise 15 questions and the sample size is 100 participants. The results were analyzed using SPSS software. The bar graphs provided depicts the results.

Results and Discussion: $87.4 \%$ of the participants think that the COVID -19 lockdown led to the loss of the only source of income of the daily laborers $.61 .2 \%$ of the participants think that the daily laborers don't have enough of their daily wages to survive this lockdown. The results obtained from the population who participated in the study depict the knowledge and awareness of the problems faced by the daily laborers during the lockdown.

Conclusion: The study confirms that the public is aware of the economic and food crisis faced by the daily laborers during the lockdown.

Key Words: Daily laborers; Lockdown; Daily wages; Economic crisis; COVID-19; Poverty.

\section{INTRODUCTION}

In December 2019, a group of pneumonia cases, brought about by a recently distinguished $\beta$-coronavirus, happened in Wuhan, China. WHO formally named the infection as Coronavirus Disease 2019 (COVID-19) and the Coronavirus Study Group of the International Committee named it as SARS-CoV-2 ${ }^{1}$. Starting on 1 March 2020, an aggregate of 79,968 instances of COVID-19 have been affirmed in territory China including 2873 deaths $^{2}$. Studies assessed that COVID-19 consistently develops by human-to-human transmission $^{3,4}$. As a developing respiratory infectious disease, COVID-19 principally spreads through the respiratory tract, by droplets, respiratory emissions, and direct contact for a low infective dose ${ }^{5,6}$. The clinical indications of COVID-19 patients incorporate fever, cough, and fatigue ${ }^{7}$.

In order to prevent the human to human transmission of the novel coronavirus, the government has imposed a nationwide lockdown leading to the shutdown of industries and public transports. Due to the shutdown of factories and workplaces, local laborers, and migrant workers had to deal with the loss of income, food shortages, and uncertainty about their future. Thousands of migrant daily workers began walking back to their native places, with no means of transport due to the lockdown ${ }^{8,9}$. In response to this, the Central and State Governments took various measures to help them and also arranged transport facilities for the workers ${ }^{10}$. Many migrant

\section{Corresponding Author:}

Dr. Leslie Rani, Lecturer, Department of General Pathology, Saveetha Dental College and Hospitals, Saveetha Institute of Medical and Technical Sciences, Saveetha University, Chennai 77, Tamil Nadu, India; Phone: +91-9360293308; Email: leslieranis.sdc@saveetha.com

ISSN: 2231-2196 (Print)

Received: 24.07 .2020
ISSN: 0975-5241 (Online)

Revised: 22.08 .2020
Accepted: 24.09 .2020
Published: 20.10 .2020 
workers also died due to starvation, suicides, police brutality, exhaustion, road and rail accidents, and denial of timely medical care. There are about 139 million daily laborers in the country approximately, according to the World Economic Forum. The International Labour Organization has said that due to the pandemic and the lockdown, about 400 million workers have been poverty-stricken. Daily laborers in the country are mostly seen in Uttar Pradesh and Bihar, followed by Rajasthan, Madhya Pradesh, and Tamil Nadu. The cities of Mumbai and Delhi have recorded the highest number of migrant daily workers ${ }^{11,12}$. Migrant workers mainly comprise daily-wage laborers working in the manufacturing industries and constructions. Daily-wage laborers are often denied adequate healthcare, nutrition, housing, and sanitation, as many of them work in the informal sector ${ }^{13,14}$. Daily-wage laborers are mostly from rural areas but are found in cities for work. Many workers have no savings and live in factory dormitories, which were shut down due to the lockdown. Additionally, there is no central registry of migrant workers, despite the existence of the Inter-State Migrant Workmen Act, $1979^{15}$.

As the state government imposed a lockdown on 20 March in Pune, Pimpri-Chinchwad, the Mumbai Metropolitan Region, and Nagpur, thousands of migrant workers gathered at the railway stations and bus stations, seeking transport to their hometowns. Upon their return to their hometowns, migrant daily workers were feared to be carrying COVID-19 infection from the urban areas where they had been employed ${ }^{16,17}$. They also faced assault and harassment from the people in their hometowns. Migrants traveled by trains have reported that food and water were not provided properly and were dumped at the train's entrance, leaving behind the laborers fighting for their share of resources ${ }^{18,19}$. Many migrant workers have expressed a fear of returning to their old jobs in the cities, after facing unemployment during the lockdown. Industries and other private sectors have already reported labor shortages from Mid- April. And reports and estimates suggest that this pandemic would last for at least another six months. ${ }^{20,21}$. The recent COVID-19 outbreak has been deemed a global health emergency ${ }^{22}$. Because of this outbreak, there is a numerable decline in the state of economy across the globe which affects the general population and the underprivileged people ${ }^{23}$. The aim of this study is to create knowledge about the crises and to create awareness about the problems faced by the daily laborers during the COVID-19 lockdown.

\section{MATERIALS AND METHOD}

This was an online study setting with a sample size of 100 participants. The survey was conducted by May 2020 in Thiruvalluvar district. The sampling method used was simple random sampling with minimal sampling bias. The questionnaire comprised 15 questions and the method of repre- senting each output variable was represented in the form of a bar graph or pie charts.

\section{STATISTICAL ANALYSIS}

The results were analyzed using SPSS statistical software and the type of analysis was the Chi-square test.

\section{QUESTIONNAIRE}

1) Gender

- Male

- Female

2) Educational level

- High school or diploma

- Diploma

- Bachelor

- Master's

3) Do you think the COVID-19 lockdown led to the loss of only source of income of the daily laborers?

- Yes

- No

4) Do you think that the daily laborers have enough of their daily wages to survive this lockdown?

- Yes

- No

5) Who do you think is the most affected due to the cut down of daily wages?

- Street Vendors

- Barbers

- Laundry workers

- Tailors

- Construction workers

6) Migrant daily laborers are most affected when compared to the local laborers.

- True

- False

7) Why do you think the migrant daily workers are most affected?

- No ration card

- Lack of transport arrangements to their native places

- Fear that they may spread virus

- All of the above

8) Livelihood of daily laborers have been?

- Partially affected

- Fully affected

9) Do you think the daily laborers get support from the state through any programmes and schemes?

- Yes

- No

- No idea

10) Daily laborers are mostly found in ?

- Industries 
- Constructions

- Others

11) How do you think the daily laborers are meeting their economic crises?

- Previous week wages

- Borrowing money

- Alternate jobs

12) Workers under healthcare and sanitation sectors still get their daily wages?

- True

- False

\section{RESULTS AND DISCUSSION}

The survey was conducted among 100 volunteers. Figure 1 shows that $88.24 \%$ are aware that the lockdown led to the loss of the only source of income of daily laborers. The daily workers were at that point confronting issues with low wages and livelihoods in the pre-COVID-19 period ${ }^{24}$. Figure 2 shows that $61.76 \%$ of the participants do not think the daily laborers have enough of their daily wages to survive this lockdown. The more drawn out the emergency keeps going, the more troublesome it will be for firms to remain above water. These will contrary influence creation in practically all domestic industries ${ }^{25}$. This will have a further overflow on investment, employment, income, and consumption, pulling down the aggregate growth rate of the economy ${ }^{26}$.

Figure 3 shows that $32.35 \%$ of the participants think that the construction workers are the most affected due to the cut down of daily wages. Few migrants pass on in transit due to a lack of food and resources ${ }^{27}$. Reports suggest that people with cancers are very vulnerable to SARS-CoV-2 infection. The additional risks associated with this infection are, the infection can spread to the lungs for the young mothers and pregnant women ${ }^{28}$, and can also cause ophthalmic problems such as stye ${ }^{29}$. Figure 4 shows that $89.22 \%$ of the participants think that migrant laborers are the most affected migrant laborers because of their exceptional and disadvantageous position are most affected due to all the hazard factors ${ }^{30}$.

Figure 5 shows that $48.04 \%$ of the participants think that migrant daily workers are the most affected when compared to the daily laborers. In India, there are about 40 to 50 million daily laborers. These laborers engage themselves in the construction of buildings and roads, factory production for daily wages. Huge numbers of migrant laborers from a few states go back to their native places by walking ${ }^{31}$. These workers would most probably have food, nourishment, and securityrelated issues especially the kids and women ${ }^{32}$. The migrants are currently unemployed as organizations and foundations have shut down. In the absence of money, jobs, food, savings, or shelter in large cities, they are desperate to reach their villages. Migrants also die on their way because of the absence of food ${ }^{27}$.
Figure 6 shows that $63.73 \%$ of the participants think that the daily laborers are fully affected due to lockdown. The daily workers are at a point confronting issues with low wages and livelihoods from the pre-COVID-19 period. Daily wage laborers and other informal laborers face the most terrible hit during the lockdown time frame and will keep on being unfavorably influenced in any event, when the lockdown is $\operatorname{loose}^{24}$.

Figure 7 shows that $41.18 \%$ are aware that the daily laborers get support from the state through programmes and schemes. The people in a worldwide COVID-19 pandemic, which is perpetrating two sorts of shock on nations: a health shock ${ }^{33}$ and an economical shock ${ }^{34}$. Given the idea of the disease which is exceptionally infectious, the approaches to contain the spread incorporates strategy activities, for example, the imposition of social distancing, self-isolation at home, closure of institutions, and public facilities, restrictions on mobility, and even lockdown of an entire country ${ }^{35,36}$. These activities can conceivably prompt critical ramifications for economies around the globe. The Bacille Calmette-Guérin (BCG) vaccine has beneficial nonspecific (off-target) effects on the immune system in protecting the health-care workers and other vulnerable individuals against severe COVID-19 infection ${ }^{37,38,39}$.

Figure 8 shows that $48.04 \%$ are aware that daily laborers are mostly found in construction. The majority (48.04\% red) think that the daily workers are mainly found in constructions, the minority (23.53\% green) says other sectors, and the rest $(28.43 \%$ blue) say the daily workers are found in industries. There are around 40 to 50 million migrant workers in India. They help in the construction of urban buildings, roads, factory production, and participate in several service activities $^{32}$. Figure 9 shows that $57.84 \%$ are aware that daily laborers meet their economic crises by borrowing money. Social imbalances between various social gatherings as far as sexual orientation, training, race, salary, language, customs and conventions, and territories of habitation are reliably connected with basic mental issues ${ }^{40,41}$. Migrant laborers because of their exceptional and disadvantageous position are especially helpless against all these hazard factors ${ }^{30}$.

Figure 10 shows that $78.43 \%$ of the participants are aware that the workers under the healthcare and sanitation sectors still get their daily wages. Boots, impermeable aprons, or coverall suits required as routine personal protective equipment (PPE) for healthcare workers and sanitation sector workers caring for patients ${ }^{42}$. Figure 11 representing the association between gender and awareness on the loss of a source of income of the daily laborers, the p-value was $0.465(>0.05)$ and it is statistically not significant. Figure 12 representing the association between gender and awareness about who was the most affected due to the cut down of daily wages, the p-value was $0.815(>0.05)$ and it is statistically not 
significant. Figure 13 representing the association between gender and awareness that the migrant daily laborers are most affected when compared to the local laborers, the pvalue was $0.870(>0.05)$ and it is statistically not significant. Figure 14 representing the association between gender and awareness on how the migrant daily workers are affected, the p-value was $0.335(>0.05)$ and it is statistically not significant. Figure 15 representing the association between gender and awareness on how the daily laborers meet their economic crisis, the p-value was $0.175(>0.05)$ and it is statistically not significant.

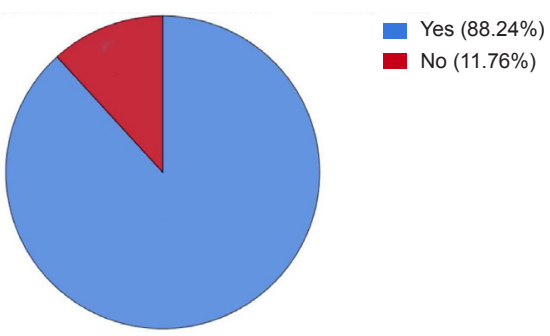

Figure 1: Pie chart showing percentage distribution about the loss of income for the daily laborers due to COVID-19 lockdown. Wherein, the blue color represents yes( $88.24 \%)$ and the red color represents no(11.76\%).

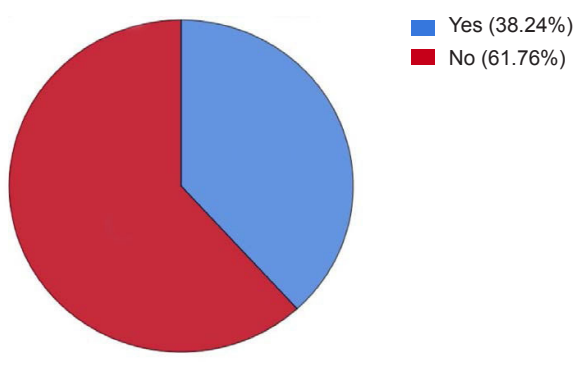

Figure 2: Pie chart showing percentage distribution about the sufficiency of daily wages to survive this lockdown. Wherein the red color represents yes $(61.76 \%)$ and the blue color represents no $(38.24 \%)$.

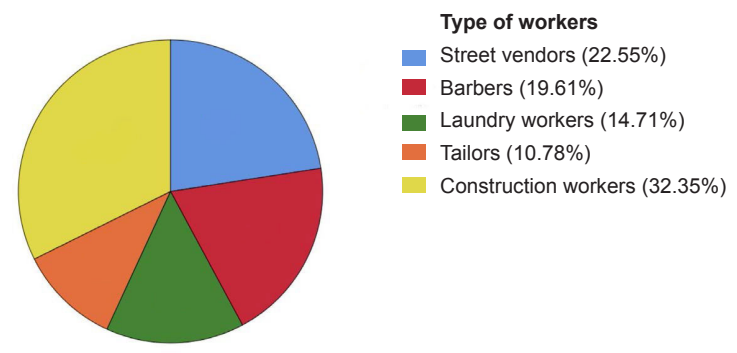

Figure 3: Pie chart showing the percentage distribution of the most affected type of daily workers. Wherein the yellow color represents construction workers $(32.35 \%)$, the blue color represents the street vendors $(22.55 \%)$, the red color represents barbers $(19.61 \%)$, the green color represents the laundry workers $(14.71 \%)$ and the orange color represents the tailors $(10.78 \%)$.

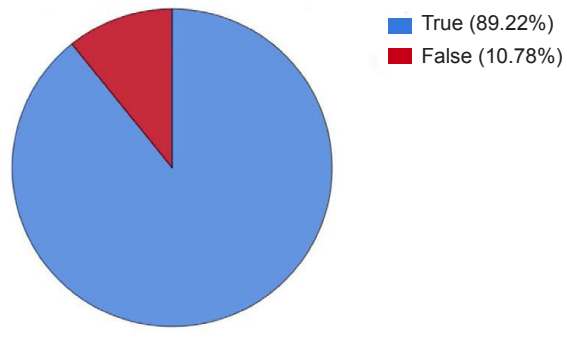

Figure 4: Pie Chart showing percentage distribution about the migrant daily laborers being more affected. Wherein, blue colour represents true (89.22\%), red colour represents false (10.78\%).

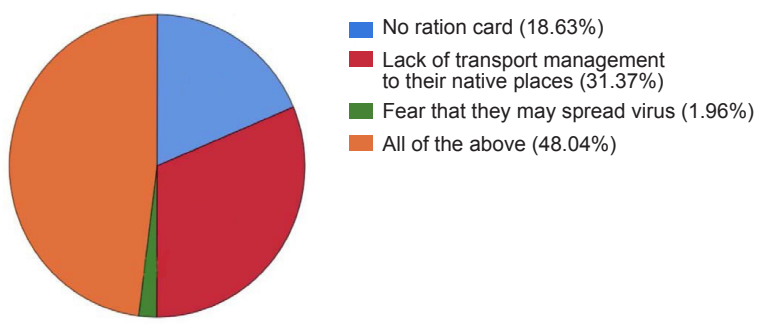

Figure 5: Pie chart showing the percentage distribution of the reasons for the migrant daily workers to be the most affected. Wherein, orange color represents all of the above(48.04\%), red color represents lack of transport arrangements to their native places $(31.37 \%)$, the blue color represents no ration card $(18.67 \%)$, green color represents the fear that they may spread the virus( $1.96 \%)$.

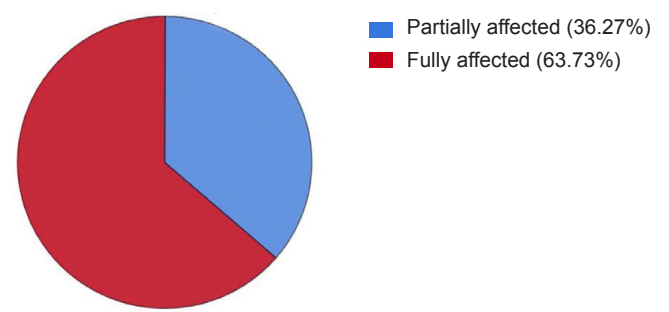

Figure 6: Pie Chart showing the percentage distribution of livelihood of the daily laborers. Wherein, red color represents partially affected $(63.73 \%)$ and blue color represents fully affected $(36.27 \%)$.

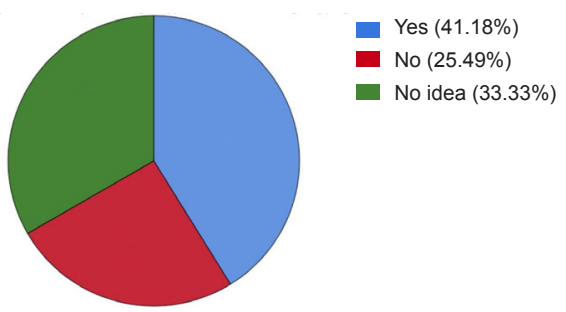

Figure 7: Pie chart showing percentage distribution about the support daily laborers get from the state through any programmes and schemes. Wherein the blue color represents yes $(41.18 \%)$, the green color represents no $(33.33 \%)$ and the red color represents no idea $(25.49 \%)$. 


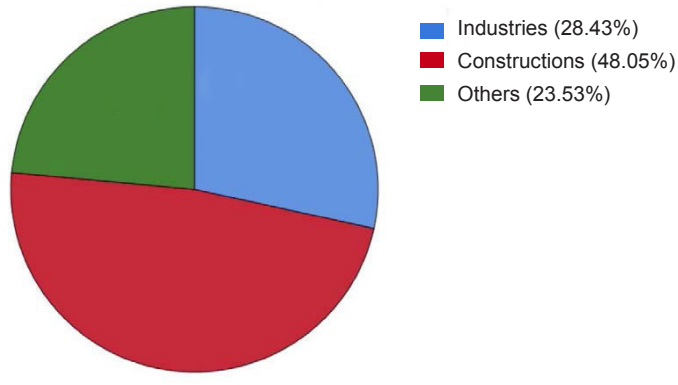

Figure 8: Pie chart showing percentage distribution on the awareness about where the daily laborers are mostly found in. Wherein the red color represents the constructions (48.04\%), the blue color represents the industries $(28.43 \%)$ and the green color represents the others $(23.53 \%)$.

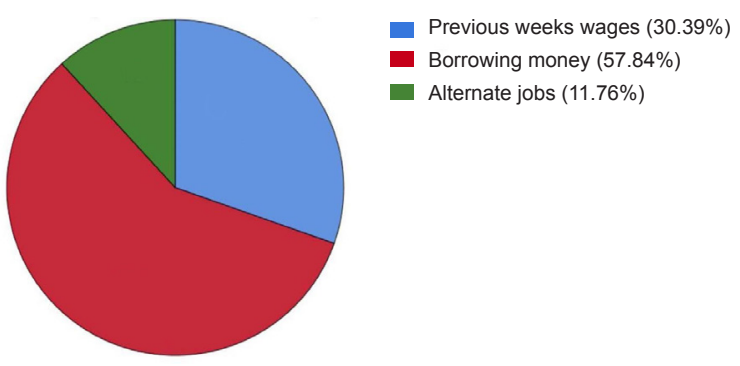

Figure 9: Pie chart showing percentage distribution on the source of income for daily laborers to meet their economic crises. Wherein the red color represents borrowing money $(57.84 \%)$, the blue color represents the previous week's wages $(30.39 \%)$ and the green color represents alternate jobs $(11.76 \%)$.

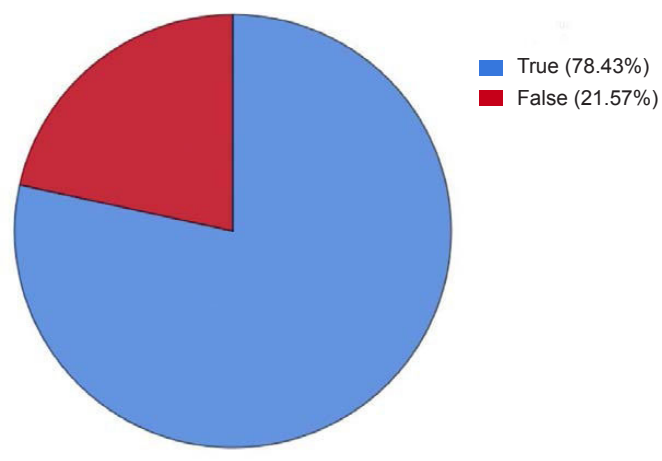

Figure 10: Pie chart showing percentage distribution on whether the workers under healthcare and sanitation sectors still get their daily wages. Wherein the blue color represents true $(78.43 \%)$ and the red color represents false ( $21.57 \%)$.

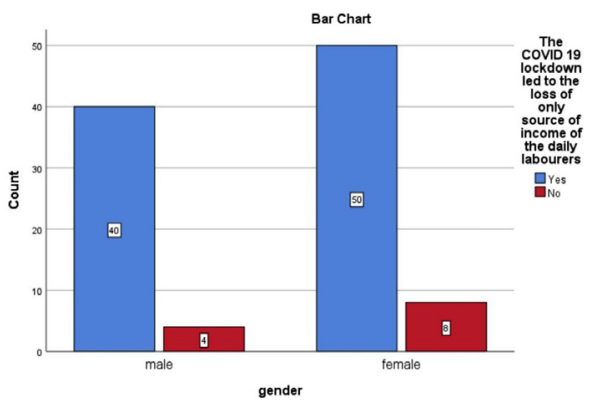

Figure 11: Bar graph showing an association between the genders and their awareness on the loss of the only source of income of the daily laborers .X-axis represents the gender and the $\mathrm{Y}$-axis represents the number of participants. A higher number of female respondents are aware that the COVID-19 lockdown led to the loss of the only source of income for daily laborers (50-blue). (Chi-square test value $=0.533$ and $p$-value $=$ $0.465, p>0.05$, which is not statistically significant).

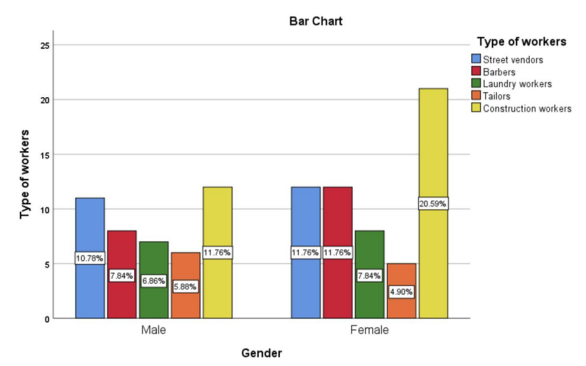

Figure 12: Bar graph shows the association between the genders and their awareness about who was the most affected due to the cut down of daily wages.X-axis represents the gender and the $\mathrm{Y}$-axis represents the number of participants. A higher number of female respondents are aware that construction workers are the most affected(20.59\%- yellow). (Chisquare test value $=1.563$ and $p$-value $=0.815,(p>0.05)$ and it is statistically not significant).

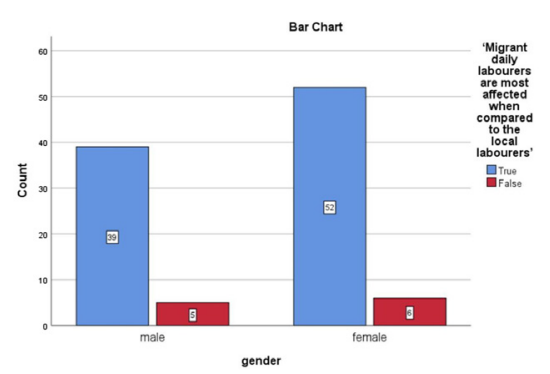

Figure 13: Bar graph showing an association between the genders and their awareness that the migrant daily laborers are most affected when compared to the local laborers. The $\mathrm{X}$-axis represents the gender and the $\mathrm{Y}$-axis represents the number of participants. A higher number of female respondents are aware that migrant daily laborers are the most affected(52- blue).(Chi-square test value $=0.027$ and $p$-value $=$ $0.870, p>0.05$, which is not statistically significant). 


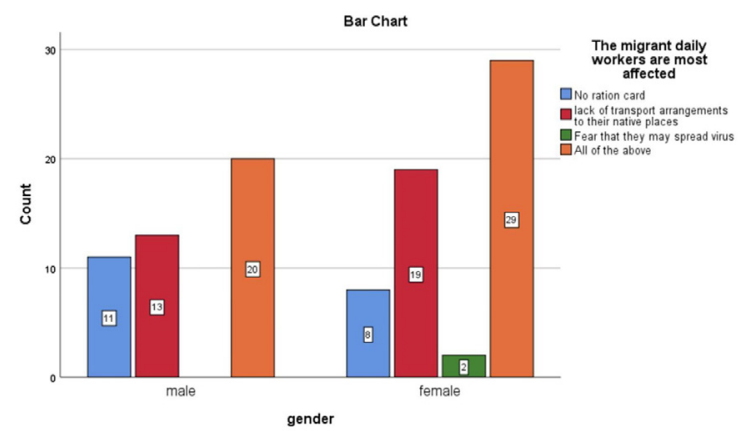

Figure 14: Bar graph showing an association between the genders and their awareness on how the migrant daily workers are affected. The $\mathrm{X}$-axis represents the gender and the $\mathrm{Y}$-axis represents the number of participants. A higher number of female respondents are aware that the migrant daily workers are most affected due to no ration cards, lack of transport arrangements to their native places, and the fear that they may spread the virus. (29- orange).(Chi-square test value $=3.394$ and $p$ value $=0.335, p>0.05$, which is not statistically significant).

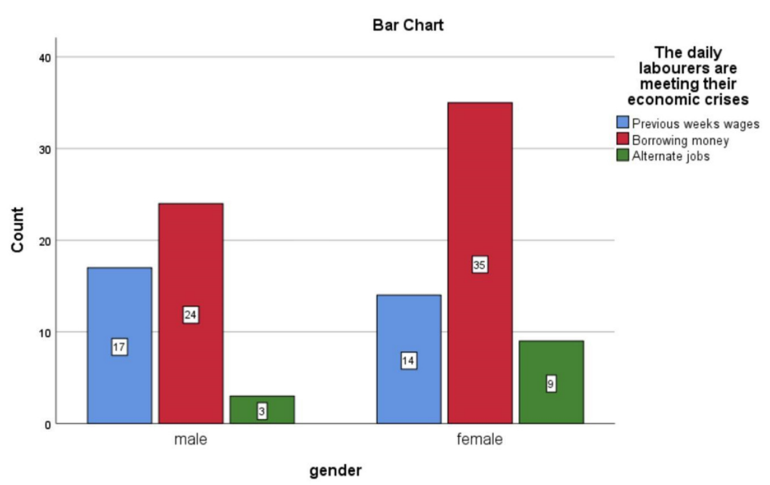

Figure 15: Bar graph showing an association between the genders and their awareness on how the daily laborers meet their economic crisis.X-axis represents the gender and the $\mathrm{Y}$ axis represents the number of participants. A higher number of female respondents are aware that daily laborers borrow money to meet their economic crises(35-red).(Chi-square test value $=3.485$ and $p$-value $=0.175, p>0.05$ which is not statistically significant).

\section{CONCLUSION}

The COVID-19 outbreak was declared a global health emergency. And there is a numerable decline in the state of economy across the globe due to the outbreak which eventually affects the underprivileged people. Migrant workers have expressed a fear of returning to their old jobs in the cities, after facing unemployment during the lockdown. Industries and other private sectors have already reported labor shortages from Mid-April. And this pandemic is likely to get extended for another six months. The result obtained from the population who participated in the study depicts the knowl- edge and awareness of the problems faced by the daily laborers during the lockdown. The present study confirms that the public is aware of the economic and food crisis faced by the daily laborers during the lockdown. And the government should also implement a scheme so as to provide daily needs to the laborers. Hence, the problems faced by the daily laborers during lockdown have been analyzed.

\section{ACKNOWLEDGEMENT}

The authors are thankful to Saveetha Dental college for providing a platform to express our knowledge and we acknowledge the immense help received from the scholars whose articles are cited and included in references of this manuscript.

\section{Conflict of Interest}

No potential conflict of interest relevant to this article was reported.

\section{Financial Support}

This research did not receive any specific grant from funding agencies in the public, commercial, or not-for-profit sectors.

\section{REFERENCES}

1. Al Dahdah M, Ferry M, Guérin I, Venkatasubramanian G. The Covid-19 Crisis in India. 2020 Apr 13 [cited 2020 May 14]; Available from: https://booksandideas.net/The-Covid-19-Crisisin-India.html

2. Alvarez FE, Argente D, Lippi F. A Simple Planning Problem for COVID-19 Lockdown [Internet]. National Bureau of Economic Research; 2020. (Working Paper Series). Available from: http:// www.nber.org/papers/w26981

3. Arya S, Gupta R. COVID-19 outbreak: Challenges for Addiction services in India. Asian J Psychiatr [Internet]. $2020 \mathrm{Apr}$ 14;51:102086. Available from: http://dx.doi.org/10.1016/j. ajp.2020.102086

4. Brundha MP, Nallaswamy D. Hide and seek in pathology- A research on game-based histopathology learning. IJRPS [Internet]. 2019 Apr 29 [cited 2020 Jun 7];10(2):1410-4. Available from: https://www.pharmascope.org/index.php/ijrps/article/view/606

5. Bhattacharyya A, Bhowmik D, Mukherjee J. Forecast and interpretation of daily affected people during 21 days lockdown due to COVID 19 pandemic in India. medRxiv [Internet]. 2020; Available from: https://www.medrxiv.org/content/10.1101/2020 .04.22.20075572v1.abstract

6. Timothy CN, Samyuktha PS, Brundha MP. Dental pulp Stem Cells in Regenerative Medicine - A Literature Review [Internet]. Vol. 12, Research Journal of Pharmacy and Technology. 2019. p. 4052. Available from: http://dx.doi.org/10.5958/0974360x.2019.00698.x

7. De Sousa A, Mohandas E, Javed A. Psychological interventions during COVID-19: Challenges for low and middle income countries. Asian J Psychiatr [Internet]. 2020 Apr 24;51:102128. Available from: http://dx.doi.org/10.1016/j.ajp.2020.102128

8. Brundha MP, Pathmashri VP, Sundari S. Quantitative Changes of Red Blood cells in Cancer Patients under Palliative Radiotherapy-A Retrospective Study. Research Journal of Pharmacy 
and Technology [Internet]. 2019;12(2):687-92. Available from: http://www.indianjournals.com/ijor.aspx?target=ijor:rjpt\&volu $\mathrm{me}=12$ \&issue $=2$ \&article $=041$

9. Prashaanthi N, Brundha MP. A Comparative Study between Popplet Notes and Conventional Notes for Learning Pathology. Research Journal of Pharmacy and Technology [Internet]. 2018;11(1):175-8. Available from: http://www.indianjournals. com/ijor.aspx ?target $=$ ijor:rjpt $\&$ volume $=11 \&$ issue $=1 \&$ artic le $=032$

10. Shreya S, Brundha MP. Alteration of Haemoglobin Value in Relation to Age, Sex and Dental Diseases-A Retrospective Correlation Study. Research Journal of Pharmacy and Technology [Internet]. 2017;10(5):1363-6. Available from: http://www.indianjournals.com/ijor.aspx?target $=$ ijor:rjpt $\&$ volume $=10 \&$ issue $=5$ \&article $=016$

11. Sowbaraniya SM, Preejitha VB, Brundha MP. Knowledge, awareness, and attitude on dental post-operative complications in diabetes among general population. Drug Invention Today [Internet]. 2020;13(2). Available from: http://search.ebscohost. com/login.aspx?direct=true \&profile=ehost\&scope $=$ site \&authty pe $=$ crawler \&jrnl $=09757619 \& A N=142963132 \& \mathrm{~h}=\mathrm{hZhkxsbCk}$ jijfyjX019\%2FCMrT\%2BBIENoXxBKcNeFlHXA5GZ2VICI4 1AOpDhyabS4WF0YGNWrxJ2Jxd2agjcHLYKw\%3D\%3D\&c $\mathrm{rl}=\mathrm{c}$

12. Preethikaa S, Brundha MP. Awareness of diabetes mellitus among general population. Research Journal of Pharmacy and Technology [Internet]. 2018;11(5):1825-9. Available from: http://www.indianjournals.com/ijor.aspx?target=ijor:rjpt\&volu me $=11$ \& issue $=5$ \&article $=024$

13. Naveenaa N, Rani SL, Brundha MP. Knowledge, attitude, and perception on the importance of hematological report among general population. Drug Invention Today [Internet]. 2020; Available from: http://search.ebscohost.com/login.aspx?direct$=$ true $\&$ profile $=$ ehost $\&$ scope $=$ site $\&$ authtype $=$ crawler $\&$ jrnl $=097$ 57619\&AN=142963163\&h=r23JtlwfC89ogG\%2FE0tW\%2Bo m\%2BOroi72NLa0ia7GzT1X3y9hjNrUiVEygOELjFcYXkkVf oEzgEe\%2FjOkd\%2F5wm9qAKQ\%3D\%3D\&crl=c

14. Dhivyadharshini J, Brundha MP. Comparison of effects of interpretation of lab reports among the undergraduate dental students. Drug Invention Today [Internet]. 2020;14(3). Available from: http://search.ebscohost.com/login.aspx?direct=true\&prof ile $=$ ehost \&scope $=$ site \&authtype $=$ crawler \&jrnl $=09757619 \& A N$ $=142952404 \& \mathrm{~h}=\mathrm{CtKh} 8 \mathrm{FPaNJB} 8 \mathrm{xtqN} 068$ isJYE7IBLrJT6q $\% 2$ FVw7pZ1RL9InbBBTTNOb9gbF9M3dTLnd744BLbsCxY\%2 B6yfsnDYpBQ\%3D\%3D\&crl=c

15. Rexlin PE, Preejitha VB, Brundha MP. Age-related differences of heart rate and respiratory rate in the age group of 45-55 years--A regression analysis. Drug Invention Today [Internet]. 2020;14(2). Available from: http://search.ebscohost.com/login. aspx? direct $=$ true $\&$ profile $=$ ehost $\&$ scope $=$ site \&authtype $=$ crawle r\&jrnl=09757619\&AN=142963149\&h=vKYUHiRXySSXXik rXcEUHJbDUiGZ7CR\%2F1J3Qe6995dq8rEU9fWnVt9mCyU RQEDSyru9X8EYPiPQ5Ja94UIYOog\%3D\%3D\&crl=c

16. Malay KK, Duraisamy R, Brundha MP. Awareness regarding anemia among 1st year dental undergraduate students. Drug Invention [Internet]. 2018; Available from: http://search.ebscohost.com/login.aspx ?direct $=$ true $\&$ profile $=$ ehost\&scope $=$ site \&a uthtype $=$ crawler $\&$ jrnl $=09757619 \& A N=130903213 \& \mathrm{~h}=6$ IXGX Y2FNBcKId5DHNd2dXCfxQJr\%2BzLQ09XGxxxBIbvGS1xd IHRzzZ6fYcY3h1vs3IDexIiUCaAeQcyAj0uKKQ\%3D\%3D\& $\mathrm{crl}=\mathrm{c}$

17. Kumar MD, Brundha MP. Awareness about nocturia-A questionnaire survey. Research Journal of Pharmacy and Technology [Internet]. 2016;9(10):1707-9. Available from: http://www. indianjournals.com/ijor.aspx?target=ijor:rjpt $\&$ volume $=9 \&$ issue $=10$ \&article $=043$

18. Lakshmi S, Rani SL, Brundha MP. Blow the balloon for the ease--A cross-sectional study on wheezing patients. Drug Invention Today [Internet]. 2020; Available from: http://search.ebscohost.com/login.aspx?direct $=$ true $\&$ profile $=$ ehost $\&$ scope $=$ site \&a uthtype $=$ crawler \&jrnl $=09757619 \& A N=142963148 \& \mathrm{~h}=39$ ATU PKb6a23SvNugwBM0uKx9O\%2FJC6dft0UosZHFg5eKqP1U uxeemfNsGIWitOTDzIp\%2Fr\%2Fq5zCNuOj3OeLZUnA\%3D $\% 3 \mathrm{D} \& \mathrm{crl}=\mathrm{c}$

19. Brundha MP. A Comparative Study-The Role of Skin and Nerve Biopsy in Hansen's Disease. Res J Pharm Biol Chem Sci [Internet]. 2015; Available from: https:/www.researchgate.net/ profile/Brundha_Mp/publication/283561218_A_comparative_ study-_the_role_of_skin_and_nerve_biopsy_in_hansen's_disease/links/5892ba5d 458515 aeac946451/A-comparative-studythe-role-of-skin-and-nerve-biopsy-in-hansens-disease.pdf

20. Kalaiselvi R, Brundha MP. Prevalence of hysterectomy in South Indian population. Research Journal of Pharmacy and Technology [Internet]. 2016;9(11):1941-4. Available from: http://www. indianjournals.com/ijor.aspx?target=ijor:rjpt\&volume $=9 \&$ issue $=11$ \&article $=027$

21. Hannah R, Ramani P, Brundha MP, Sherlin HJ, Ranjith G, Ramasubramanian A, et al. Liquid Paraffin as a Rehydrant for Air Dried Buccal Smear. Research Journal of Pharmacy and Technology [Internet]. 2019;12(3):1197-200. Available from: http:// www.indianjournals.com/ijor.aspx?target=ijor:rjpt\&volume $=12$ \&issue $=3$ \&article $=038$

22. Dev SM, Sengupta R, Others. Covid-19: Impact on the Indian economy [Internet]. Indira Gandhi Institute of Development Research, Mumbai, India; 2020. Available from: http://www.igidr. ac.in/pdf/publication/WP-2020-013.pdf

23. Grills N. COVID-19 and Containment: A Dual Burden for India. Christian Journal for Global Health [Internet]. 2020; Available from: https://journal.cjgh.org/index.php/cjgh/article/download $/ 377 / 723$

24. Chinazzi M, Davis JT, Ajelli M, Gioannini C, Litvinova M, Merler $\mathrm{S}$, et al. The effect of travel restrictions on the spread of the 2019 novel coronavirus (COVID-19) outbreak. Science [Internet]. 2020 Apr 24;368(6489):395-400. Available from: http:// dx.doi.org/10.1126/science.aba9757

25. Suryawanshi R. A Study of Impact of COVID-19 Outburst and Lockdown on Business of Small Proprietors and Businesses in Maharashtra State. Purakala with ISSN 0971-2143 is an UGC CARE Journal [Internet]. 2020;31(12):215-24. Available from: https://www.purakala.com/index.php/0971-2143/article/ view/646

26. Singh OP. Mental health of migrant laborers in COVID-19 pandemic and lockdown: Challenges ahead. Indian J Psychiatry [Internet]. 2020 May 1 [cited 2020 May 20];62(3):233. Available from: http://www.indianjpsychiatry.org/article.asp?issn=00195545 ; ear $=2020$; volume $=62 ;$ issue $=3 ;$ spage $=233$; epage $=234 ;$ au last $=$ Singh

27. Ranscombe P. Rural areas at risk during COVID-19 pandemic. Lancet Infect Dis [Internet]. 2020 May;20(5):545. Available from: http://dx.doi.org/10.1016/S1473-3099(20)30301-7

28. Balaji S, Brundha MP, Path DNB. Awareness of About Breast Cancer among Dental Surgeons. Res J Pharm Biol Chem Sci [Internet]. 2016;8(8):797. Available from: https://pdfs.semanticscholar.org/63f4/4173d90b35bffa33eed0aeb52ac547ef1567.pdf

29. Ferdioz J, Brundha MP. Awareness of Stye.International Journal of Pharmaceutical Sciences Review and Research [Internet].2016;40(1):30-32. Available from: http://globalresearchonline.net/journalcontents/v40-1/08.pdf 
30. Shaikh A, Mishra K. The Impact of the Lockdown on India's Informal Sector. Studies in Indian Place Names [Internet]. 2020;40(68):519-23. Available from: https://archives.tpnsindia. org/index.php/sipn/article/view/8809

31. Sohrabi C, Alsafi Z, O'Neill N, Khan M, Kerwan A, Al-Jabir A, et al. World Health Organization declares global emergency: A review of the 2019 novel coronavirus (COVID-19). Int J Surg [Internet]. 2020 Apr;76:71-6. Available from: http://dx.doi. org/10.1016/j.ijsu.2020.02.034

32. Wu Z, McGoogan JM. Characteristics of and important lessons from the coronavirus disease 2019 (COVID-19) outbreak in China: summary of a report of 72314 cases from the Chinese. JAMA [Internet]. 2020; Available from: https://jamanetwork. com/journals/jama/article-abstract/2762130

33. P Jannathulferdioz BM. Awareness of Stye. Int J Pharm Sci Rev Res,. 40(1):30-2.

34. Loopstra R. Vulnerability to food insecurity since the COVID-19 lockdown [Internet]. The Food Foundation; 2020. Available from: https://foodfoundation.org.uk/wp-content/uploads/2020/04/Report_COVID19FoodInsecurity-final.pdf

35. Narayanan S, Saha S, Others. Urban food markets and the lockdown in India [Internet]. Indira Gandhi Institute of Development Research, Mumbai, India; 2020. Available from: http://www.igidr.ac.in/pdf/publication/WP-2020-017.pdf

36. Harsha L, Brundha MP. Prevalence of dental developmental anomalies among men and women and its psychological effect in a given population. Res J Pharm Biol Chem Sci [Internet]. 2017;9(6):869. Available from: http://search.proquest. com/openview/1f488cc6e377096f44a87e509aceab79/1?pqorigsite $=$ gscholar $\&$ cbl $=54977$

37. Swetha G, Rani SL, Brundha MP. Awareness of the side effects of vaccination among general public. Drug Invention Today
[Internet]. 2020;14(3). Available from: http://search.ebscohost. com/login.aspx?direct $=$ true \&profile $=$ ehost\&scope $=$ site \&autht ype $=$ crawler \&jrnl $=09757619 \& A N=142952406 \& \mathrm{~h}=$ cfy $4 \mathrm{iVQX}$ TmraHT0MJ57kCwWVNs2PNhY2Y7nJTwJVVA3EMfUhVO CFiNRILWi0alMic7UTOupw7U422FIqfdtOVQ\%3D\%3D\&cr $\mathrm{l}=\mathrm{c}$

38. Sarvesh Kumar J, Brundha MP. Awareness about childhood vaccination among parents with children below 15 years of age. Drug Invention Today [Internet]. 2018;10(12). Available from: http://search.ebscohost.com/login.aspx?direct=true\&profile $=$ eh ost \&scope $=$ site $\&$ authtype $=$ crawler $\&$ jrnl $=09757619 \& A N=132$ 447040\&h=2WpShrfu\%2BS1TcRwVn20QzXQmGi0LTVw80 07Sf3e5Ps0hFqxpLBw\%2Fk91HZB\%2FzP\%2Fw\%2BmIN5Y M6Eu4FTDn8aIdinZg\%3D\%3D\&crl=c

39. Monaco WA. The Impact of COVID-19 on Residents of Skilled Care Facilities Throughout the United States [Internet]. Vol. 12, International Journal of Current Research and Review. 2020. p. 01-01. Available from: http://dx.doi.org/10.31782/ ijcrr.2020.121617

40. Rajagopalan S, Tabarrok AT. Pandemic Policy in Developing Countries: Recommendations for India [Internet]. Mercatus Special Edition Policy Brief. 2020 [cited 2020 May 14]. Available from: https://papers.ssrn.com/abstract=3593011

41. Shenoy PB, Brundha MP. Awareness of polycystic ovarian disease among females of age group 18-30 years. Res J Pharm Biol Chem Sci [Internet]. 2016;8(8):813. Available from: http:// search.proquest.com/openview/a8a09e7b2e9d2f967bf3fee479c 7018a/1?pq-origsite $=$ gscholar $\& \mathrm{cbl}=54977$

42. Ravichandran H, Brundha MP. Awareness about personal protective equipments in hospital workers (sweepers and cleaners). International Journal of Pharmaceutical Sciences Review and Research. 2016;40(1):28-9. 